\title{
The Ethics of Alternative Currencies
}

\author{
Louis Larue \\ University of Gothenburg
}

Camille Meyer

University of Cape Town

Marek Hudon
Université Libre de Bruxelles

Joakim Sandberg
University of Gothenburg

\begin{abstract}
Alternative currencies are means of payment that circulate alongside-as an alternative or complement to- official currencies. While these currencies have existed for a long time, both society and academia have shown a renewed interest in their potential to decentralize the governance of monetary affairs and to bring people and organizations together in more ethical or sustainable ways. This article is a review of the ethical and philosophical implications of these alternative monetary projects. We first discuss various classifications of these currencies before analyzing the ethical challenges linked to the way they tackle social and environmental issues. We also examine the incentive-based and coercive mechanisms used by these currencies from an ethical perspective and debate the promises and perils of monetary decentralization and democracy. We conclude by identifying an agenda for future research.
\end{abstract}

Key Words: alternative currencies, complementary currencies, cryptocurrencies, nature of money, ethics of money

lternative currencies (ACs) are monies or means of payment that circulate
alongside-as an alternative or complement to-official currencies, such as
euros and dollars. These currencies have existed for a long time, and they have likely
played more or less prominent roles in the economy at various stages of history
(Gómez 2018). In recent years, there has been a renewed interest in, and enthusiasm
about, ACs in both society and academia (Cohen 2017; Seyfang and Longhurst
2013). Prominent examples of contemporary ACs include mutual exchange systems
(such as local exchange trading systems), local currencies (such as the Ithaca HOUR
and the Bristol Pound), private credit networks (such as the WIR in Switzerland),
and cryptocurrencies (such as Bitcoin). Their proponents have argued that ACs are
driven by ethical goals. For instance, local currencies have been hailed for their
ability to curb the excesses of the market economy and to bring people and 
organizations together in more ethical or sustainable ways (Lietaer et al. 2012; North 2007), while cryptocurrencies often are praised for their capacity to decentralize the governance of monetary affairs (Lambrecht and Larue 2018).

Previous academic research on ACs has been mainly descriptive and focused on issues like the classification of different currencies (Blanc 2018b; Larue 2020a), the motivations of users of ACs (Blanc and Fare 2016; Meyer and Hudon 2017), and ACs' impact on society and the environment (Marshall and O'Neill 2018; Seyfang and Longhurst 2013). Several recent articles have reviewed the empirical literature thoroughly and have highlighted the potential roles that ACs can play in society (Fare and Ould Ahmed 2017; Michel and Hudon 2015). However, there is also a need to situate ACs in a greater ethical and philosophical discussion, to evaluate whether they ultimately are desirable or problematic from a normative societal perspective. The ethical discussion about ACs has only just started and has so far highlighted both their positive effects and their limitations (Meyer and Hudon 2019; Dierksmeier and Seele 2018). This article is a review and synthesis of the ethical and philosophical implications of these alternative monetary projects. More precisely, we extend the ethical analysis of ACs and connect it to broader issues in the fields of business ethics and political philosophy. Our overarching aim is to stimulate further and more ambitious philosophical debate about ACs in the future.

The article is organized into four sections. The first section reviews the variability in nature and purpose of ACs that is highlighted by different classifications and typologies. Despite their diversity, we emphasize what ACs have in common and why it makes sense to group them under a common denominator. We also connect this research to the greater philosophical discussion about the nature of money and discuss whether there are limits to what can function or count as money. The second section examines the excesses of the market economy that many ACs try to address and evaluates to what extent the monetary system is an essential or contingent part of those problems. The third section analyzes the mechanisms that ACs employ to solve these problems, which include restrictions, incentives, and appeals to moral values. We relate this research to the greater normative debates about "nudging" and paternalism. The fourth section takes a different road and concerns the issue of ACs as voluntary alternatives in a "monetary plurality," which we connect to greater political debates about decentralization and democracy.

We wish to stress that, while our main aim here is to stimulate further philosophical or theoretical research about ACs, we believe that our article also demonstrates the great practical importance of that endeavor, because as the interest in ACs continues to grow around the world, their impact on our economies and societies will also continue to grow. We may in fact be approaching a juncture in economic history where the choice of money and monetary system will feel more open than ever before, due to various technological and societal developments. This situation, of course, only increases the importance of debating and handling the many ethical issues to which different currencies and monetary systems give rise. Our hope is that the present article will stimulate a greater number of philosophers to take an interest in ACs, as well as to stimulate other researchers on ACs to take a greater interest in the background philosophical questions. 


\section{THE VARIABILITY OF ALTERNATIVE CURRENCIES}

ACs can take a number of physical or digital forms, have various internal characteristics, and rely on different external structures. In this section, we first review empirical research on this variability and recent developments of typologies and classifications. We then show how this literature raises important questions regarding the nature of money and develop it further by connecting it to philosophical discussions about the ontology and normativity of money.

\subsection{Classifying Currencies}

ACs have a long history, with early examples dating back to the Middle Ages (Fantacci 2005, 2008; Kuroda 2008). However, we focus here on more modern examples and contemporary debates. An illustrative historical overview by Blanc (2011) identifies four generations of ACs, starting with local exchange trading systems (LETS) as the first generation in the 1980s. LETS are a form of mutual credit system in which the account of each member is credited (or debited) each time the member provides (or receives) a service (Servet et al. 1999). In a second generation of ACs, so-called time exchange systems, the value of the services is instead measured in time units (Gregory 2009). The purpose of both of these systems is typically to facilitate local exchanges within a given community and to avoid the differential pricing of services on the broader market.

A third generation of ACs comprises local or regional currency schemes, such as the Ithaca HOUR or the RegioGeld, which are physical monies circulating within a confined geographic area (Degens 2016; Marshall and O'Neill 2018). Finally, a fourth generation of ACs is specifically tied to sustainability. For example, so-called green currencies allow users to earn "green points" for sustainability-related activities like recycling, and the points can then be used to buy sustainability-related products like organic food. These projects require a more sophisticated institutional setup and are typically explored in collaboration with local governments (Blanc and Fare 2013). In one sense, however, they are similar to commercial loyalty schemes, such as air miles, or other loyalty schemes that are promoted by private companies (Blanc 2018b).

It may be relevant to add a fifth generation of ACs to the list, namely, cryptocurrencies like Bitcoin. These are digital currencies whose creation processes and payment systems are decentralized and handled through an open-access protocol (De Filippi 2014; Lambrecht and Larue 2018). Cryptocurrencies are similar to other ACs in the way that they challenge or complement official currencies, and they are often motivated by similar criticisms of the prevailing monetary system. However, it should be noted that cryptocurrencies are extremely diverse in terms of their functionality and potential justification (Dierksmeier and Seele 2018). This points to a problem for classifications of ACs into simple generations, namely, that there are both differences within each generation and overlaps between them (Larue 2020a).

The complexity of the landscape of ACs has drawn several authors to propose more complex typologies with multiple dimensions and subdimensions. For example, Martignoni (2012) ranks currencies according to a long list of criteria, including 
their purpose, their issuance mechanism, their basis of trust, and their cost-recovery mechanism. Bech and Garratt (2017) propose a related typology that has been especially popular in the literature on digital currencies (Barontini and Holden 2019; Kumhof and Noone 2018; Niepelt 2020). This typology classifies currencies according to four central features: issuer (central bank or other), accessibility (universal or limited), transfer mechanism (centralized or decentralized), and form (electronic or physical).

Finally, classifications that focus on the purposes or objectives of ACs are particularly relevant to our present concerns. Three purposes emerge as central in the literature: currencies can be for profit, not for profit, or public/state sanctioned (Blanc 2013, 2018b; Lietaer and Kennedy 2008; Tichit, Mathonnat, and Landivar 2016). Following Blanc (2018b), these purposes may also be connected to different "spheres" of society, namely, the spheres of the market, the community, and the state. Currencies like air miles are obviously for profit and belong to the market sphere, local currencies and LETS are not for profit and belong to the community sphere, and the examples of green currencies are partially public and belong to the state sphere.

We do not wish to take a stand on which of these typologies is best for analytical purposes. Critical authors have argued that many of them fail to live up to reasonable standards of clarity and precision (Larue 2020a). This may impair efficient communication within a scientific community (Hodgson 2019). However, debates about normative issues or political projects are different and can often contain "contested concepts" that are classified in a variety of ways (Hacking 1999). Given the normative character of most proposals of ACs, as well as the socially constructed nature of money itself (see later), perhaps one should give up on the prospect of finding a typology that meets the expectations of all researchers and practitioners.

Yet, it is possible to draw at least two conclusions from the literature. First, what differentiates ACs from official currencies is that the former are not backed by the state but instead by either grassroots initiatives or private companies. While some ACs have partial support by local governments (such as green currencies), they are still governed primarily by their users. Second, it is fair to say that all ACs-from LETS and local currencies to Bitcoin-have been designed for a certain normative purpose, which can be social, environmental, or economic. It is presumably this purpose that makes their followers prefer the ACs over official currencies. We believe that these two features are distinct enough to treat all of the aforementioned currencies under a common denominator, and both of the features are central to our analysis of ACs in this article.

To provide further philosophical grounding to the debate about typologies, we now connect it to the larger philosophical discussion about the nature and purpose of money as such. An important question in the background is to what extent these various ACs display the central features of money and whether they really should be counted as money. The next two subsections explore debates on the ontology and normativity of money to determine whether and where different ACs may count as money. 


\subsection{The Ontology of Money}

Philosophical discussions about the ontology of money are extremely rich and diverse (for a recent survey, see De Bruin et al. 2018). In this section, we focus on two main ontological views: the functionalist perspective and the collective acceptance perspective. We believe that both shed light on interesting features of ACs and, vice versa, that ACs are interesting test cases for these theories.

It has become commonplace in the economic literature to describe money as whatever commodity or "thing" fulfills certain central functions, most importantly to 1) facilitate exchange, 2) store value, and 3) serve as a unit of account (Tobin 2008). Although the physical form of money has changed over time, it has typically been chosen for its convenience along these three dimensions - whatever is easy to carry, durable, and easily divisible. This functionalist perspective also has philosophical proponents in Hindriks and Guala $(2015,2021)$ and Smit, Buekens, and du Plessis (2016), who all argue that money's existence and persistence are best explained by its functions and their correlative economic benefits.

The functionalist account may be taken to suggest that typologies of ACs should focus on their money-like functions. But what would such a typology yield? Interestingly, it seems that the defining feature of many ACs is precisely the restriction of such functions. For instance, it is a central feature of LETS and local currencies that they cannot be used to facilitate exchanges with people outside the relevant communities. It could be argued that this lack of functionality, which has been found to limit the capacity of LETS to grow and to generate significant economic benefits, raises doubts about whether such "currencies" really deserve their name (Dittmer 2013; Marshall and O'Neill 2018). Similarly, Yermack (2015) contends that Bitcoin (and similar cryptocurrencies) should not be counted as money because it fails to be an efficient means of payment, store of value, and unit of account.

However, the functionalist camp is not united on this issue, and there are several positions on what counts as a function and how well a currency needs to fulfill that function. For instance, Smit, Buekens, and du Plessis (2016) argue that something may count as money as long as its "typical use" is to serve as a means of exchange, that is, as a device to reduce transaction costs. Because Bitcoin is not frequently and efficiently used in this way, they argue that it is more of a financial asset than money per se. Nevertheless, their account is more tolerant than Yermack's. Finally, Hindriks and Guala (2021) - perhaps the most prominent proponents of the functionalist view of money-seem to concede that something does not have to function "perfectly well" as a means of exchange to count as money. They write that all social institutions (including money) can be understood as solutions to collective action problems, but they need not be the optimal solutions to those problems because they typically have to adjust to a broader range of preferences and values (Hindriks and Guala 2021, 2037-38). This may be taken to imply that some ACs are money even though their functionality is reduced, provided that they deliver useful benefits in other ways.

Alternatively, one could argue that money should not be defined by its functions but rather that the defining feature of money is its collective acceptance in society. 
According to philosophers like Searle $(1995,2010)$ and Tuomela (2002), money is an example of an institutional fact. More precisely, Searle (1995) argues that institutional facts are created by the collective assignment of a specific kind of function - the status-function - to preexisting objects. For instance, a certain piece of paper becomes money simply when we collectively assign a special status to it ("this is money"), which involves certain functions (payment, store of value, etc.). Unlike many economists, Searle denies that the nature of money is explained by its functions (9-18). The crucial component is instead the collective recognition of something as money. According to Searle, the relevant recognition can be understood broadly and can often be informal (22-23). But whenever a certain object (e.g., a piece of paper) is recognized by a certain number of people as money, it is money, and whether it functions efficiently does not matter (Searle 2015, 508-9).

Searle's theory suggests that typologies of ACs should focus on their (current or prospective) recognition in society. Although we have not found any direct appeals to Searle in the literature on ACs, one could perhaps interpret at least some parts of the debate along these lines. First, as noted earlier, what differentiates ACs from official currencies is that the former are not backed by the state and therefore do not enjoy formal social recognition. However, authors like Servet et al. (1999) argue that LETS and local currencies are better and more "authentic" currencies than the official ones because they draw on the trust and commitment created in a community. Similarly, some proponents of Bitcoin have argued that cryptography is a stronger basis of trust than the official decrees of various political authorities because the code does not have political ambitions in the same way humans do (Nakamoto 2008). Leaving aside the normative part of these statements for now, we can conclude that at least some proponents of LETS and Bitcoin would say that they are money because people informally recognize them as money and have reasons to do so. Hence, an interesting aspect of this collective acceptance account of money, in our view, is that it highlights how a society's choice of money is indeed an open choice. That is, it is up to people to choose what kind of money they want, presumably based on a combination of different normative reasons.

What this short discussion of the ontology of money shows is that there are different ways of theorizing about the money-like features of ACs. According to functionalists, what ultimately matters is whether they serve the special functions of money. According to those who favor Searle's view, what matters is whether they are collectively recognized as money. In both cases, it is clear that different ACs will fare differently in these regards - that is, different ACs will display different levels of functionality and collective acceptance. Therefore it is likely that the debate about whether they really are money will continue.

\subsection{The Normativity of Money}

As a final point concerning the nature of money, one may wonder whether it is important to make a clear distinction between money that is chosen for explicitly normative reasons - be they "political," "social," or "environmental"- and money that is (allegedly) more "neutral." As noted, a defining feature of ACs is that they are purpose driven (Blanc 2017, 2018b; Place and Bindewald 2015; Tichit, Mathonnat, 
and Landivar 2016). This can be to varying degrees: whereas some ACs merely seek to reform the current system, others seem to challenge the very idea of markets and capitalism (Meyer and Hudon 2019; Guéorguieva-Bringuier and Ottaviani 2018). In any case, the normative nature of ACs contrasts with the apparent lack of explicit normative purpose of official currencies like euros and rand.

Against this distinction, one can argue that no money can be "neutral," with regard either to its justification or to its consequences. First, it is always created or maintained by an agent, such as the state or the central bank, based on at least implicit normative justifications. The most recent such example is the euro. As outlined in the Delors Report for the European Council (1989), the creation of the euro had clear political goals, such as enhancing European cohesion, strengthening monetary stability, and improving monetary policy coordination. Second, all currencies have real-world consequences. A recent example is again given by the euro: the European Central Bank's attempts to safeguard confidence in its currency after the 2008 financial crisis by injecting huge amounts of cash into the financial markets have, among other effects, increased wealth inequalities (Dietsch, Claveau, and Fontan 2018).

Therefore we argue that the fact that ACs are motivated by normative reasons should not make us view them as very different from official currencies. Yet, it is still worth discussing whether those normative purposes are justified and whether ACs are able to fulfill them. We turn to these questions in the next two sections, respectively.

\section{THE ETHICAL CHALLENGES OF MARKETS AND MONEY}

Multiple proponents of ACs typically claim that they can contribute to solving salient problems that are inherent to contemporary market societies. We here evaluate these arguments and assess whether the root causes of the problems really lie in money. We then make connections to how similar problems are addressed in other literatures in business ethics and political philosophy.

\subsection{How Alternative Currencies May Tackle Social and Environmental Issues}

Although different ACs have been designed to tackle different problems, we here focus on two issues that are central in the literature on ACs, namely, community integration and environmental sustainability. We also consider democratic governance later in the article (see section 4).

The main driver behind many ACs is the value of community. According to several classic authors-such as Simmel (2004), Polanyi ([1944] 2001), and Titmuss (1970) - the growth of the market economy can have at least two detrimental effects on society. First, it can lead to weaker social or communal bonds between people, thereby potentially destroying the prospects for just and democratic cooperation. Second, people may lose their sense of belonging, thereby starting to feel more isolated and alienated. These arguments have of course been contested by other authors (Bowles 1998; Seabright 2004), and we cannot review that debate in detail in this article. We focus simply on how the literature on ACs 
has made use of these arguments and how their use differs from other literatures on similar topics.

According to several proponents of ACs, part of ACs' justification stems precisely from how they promote the values of community and solidarity instead of the amoral self-interest of the market sphere (Servet et al. 1999; Lepofsky 2009; Lietaer et al. 2012; Seyfang 2002). It is argued that ACs can promote the integration of communities because they allow relative neighbors to engage with each other, instead of leaving everyone isolated at the margin of the modern economy (Degens 2016; Oliver Sanz 2016). Moreover, ACs can foster informal exchanges and mutual assistance among community members (Blanc 2018a; Fare and Ould Ahmed 2017; Lepofsky 2009). Some proponents make the stronger claim that ACs promote local economic development and thereby reduce poverty and unemployment (Williams 1996; Bowring 1998; Peacock 2000). However, subsequent empirical research has not found any significant development effects in this regard (Michel and Hudon 2015; Marshall and O'Neill 2018).

A related driver behind many ACs is the value of environmental sustainability (Brooks 2015; Seyfang and Longhurst 2013). This value hardly needs an introduction here, because all contemporary readers will be aware of the importance of reducing pollution levels and promoting a more circular economy. According to proponents of ACs, changing our currency can be helpful also in this regard. Currencies that circulate only in a smaller community (such as LETS and local currencies) can help to reduce the pollution caused by long-distance transportation and can also incentivize communally owned production facilities for "green" products, such as organic food (Gregory 2009; Lietaer et al. 2012; Joachain and Klopfert 2012, 2014). More directly, so-called green currencies (or carbon currencies) are designed to limit or eliminate transactions with carbon-intensive products and instead favor trade in sustainability-related goods and services (Seyfang 2009; Rousseaux 2010; Collins, Schuster, and Greenham 2013). This is, in essence, similar to the better-known carbon pricing programs for businesses (Boyce 2018), but here managed and applied at the level of citizens rather than companies or states.

The literature on cryptocurrencies contains at least some references to the aforementioned values as well. Perhaps the most relevant "community" here is the global community of internet users. However, there is ample evidence that Bitcoin and other cryptocurrencies have had a severely negative impact on the environment due to their high electricity needs (Mora et al. 2018).

\subsection{Alternative Analyses}

To provide further philosophical perspectives on the preceding ideas, we now analyze how some of these issues have been addressed in other parts of the literatures on business ethics and political philosophy. There is ample literature on the social and environmental issues noted earlier that makes no mention whatsoever of monetary reform or ACs. Hence our main question here is whether the root causes of the problems really lie in money or whether they lie somewhere else.

A different literature that also emphasizes the need for community integration and social reciprocity is the debate about communitarianism in political philosophy 
(Etzioni 1988; Sandel 1984; Taylor 1991). A central feature of this literature is that it opposes some of the core claims of liberalism, in particular, the ideal of autonomy or self-determination. Liberals generally hold that individuals must be free to "pursue [their] own good in [their] own way, so long as [they] do not deprive others of theirs," as argued by Mill ([1859] 1974, 72). Yet communitarian authors argue that the realization of the ideal of autonomy has significant negative drawbacks; people may start to feel detached and rootless, and they may lose all meaningful connections with others (Taylor 1991). Thus a better way of supporting people would be to support their access to community relations that produce a feeling of belonging and engagement (Etzioni 1988).

Many authors of the communitarian school share Polanyi's ([1944] 2001) negative view on the socially disruptive and alienating effects of the development of markets. However, it should be noted that this literature seldom discusses monetary reform or ACs. There is, in fact, an alternative and simpler view that many communitarians endorse. This is the idea that there must be limits to markets as such; that is, there are important spheres of social life that should be treated as off-limits to market thinking (Walzer 1983). As Sandel (2012) posits, some of the good things in life are corrupted and degraded if turned into commodities. The argument here is Kantian in nature, namely, that some things in life should be treated with dignity and respect rather than through the instrumental pricing of markets.

It is interesting to compare this line of reasoning with the arguments of $\mathrm{AC}$ proponents. According to both Polanyi and Sandel, the underlying problem stems from markets rather than from how various currencies work. It is therefore unclear why a communitarian should support the establishment of some form of AC. Following Sandel's reasoning, it may indeed be a nonstarter to try to address the problem with monetary reform or ACs, because any use of currency might entail market-style instrumental attitudes and thinking. In practice, these currencies may actually extend the scope of goods and services people trade between themselves and thus reinforce commodification, as some of their proponents have acknowledged (Blanc 2018a, 112-13).

There is, of course, an even broader literature relating to the environmental sustainability of markets. Although we cannot review much of this literature here, we note two salient debates. First, plenty of authors in business ethics have described how almost all companies nowadays engage in allegedly pro-environmental activities, which in some cases may amount to greenwashing, that is, attempts to misdescribe or exaggerate the positive environmental benefits of one's activities for pure marketing purposes (Delmas et al. 2011). To counteract greenwashing, these authors are calling for more precise standards for and measurements of the real-world impact of various business initiatives (Barnett, Henriques, and Husted 2020; Liket 2014). It is plausible to endorse only pro-environmental behavior that has a tangible impact on the environment and to give greatest support to the behaviors with the highest impact.

Second, it is fair to say that the concept of "sustainability" has become broader over the last decade or so. According to many authors, sustainability not only pertains to the environmental dimension but also includes social and economic sustainability (Giovannoni and Fabietti 2013). In 2015, the United Nations adopted 
a global agenda consisting of seventeen Sustainable Development Goals, and these include concerns of environmental, social, and economic natures. They are sometimes summarized by the "Five $P$ s": people, planet, prosperity, peace, and partnership. It is in particular emphasized that increased sustainability in one dimension should not come at the cost of decreased sustainability in another (United Nations 2015).

Coming back to our analysis of ACs, we believe that the preceding insights can provide some useful guidance. First, while many proponents of ACs have stressed ACs' high ambitions with regard to environmental sustainability, it is not clear at this point whether they have any real-world impact. The limited number of empirical studies that have been performed in this regard have not yet been able to track any significant impact (Michel and Hudon 2015; Marshall and O'Neill 2018). This is generally explained by ACs' relatively small size and lack of broader recognition. Moreover, at least some authors have argued that other policy instruments seem better designed than ACs to tackle environmental challenges. For instance, Dittmer (2013) argues that ACs provide only a decentralized and piecemeal attempt at a solution, whereas more profound monetary reforms - such as "sovereign money"are more likely to have system-level effects. Sovereign money would mean that only the state retains the authority to create new money and therefore the influence of the commercial banking system would be severely restricted in this regard (for a critical analysis, see Huber and Robertson 2000). We return to issues concerning effectiveness in the next section.

Second, is there a risk that the environmental objectives of ACs can come into conflict with other sustainability objectives? As we have seen, some ACs aim at benefiting the environment by giving priority to the local economy, as opposed to the global economy. The main argument here is that buying local contributes to reducing the environmental pollution caused by global trade (Schnell 2013; Cleveland, Carruth, and Mazaroli 2015). However, it might be argued that, in some cases, favoring the local economy may harm the poor in the Global South (Ferguson and Thompson 2021). Some authors have therefore argued that, rather than favoring the local solution, one should instead attempt to offset the harms of global trade by purchasing carbon offsets, so as to retain the benefits of trade while reducing its harms (Ferguson and Thompson 2021). If they are right, it is unclear what place should be left to ACs and other schemes that favor the local economy at the expense of global trade.

To summarize, we have used the broader literature on sustainability in markets to identify at least two challenges that need further attention from the AC community. First, more effort needs to be put into increasing ACs' impact on the environment. Second, that impact should not come at the expense of people in the Global South who are already worse off than others.

\section{THE MECHANISMS OF ALTERNATIVE CURRENCIES}

How would ACs address the social and environmental problems described herein? This section concerns the mechanisms that ACs use to influence their users' 
activities. Although the literature rarely discusses these mechanisms in a critical light, we think that such a discussion is central to an ethical analysis of both the benefits and the drawbacks of ACs. For even if the purposes of ACs are valuable, we must take a critical look at the mechanisms through which they are meant to fulfill them. We investigate three central mechanisms: restrictions, incentives, and an appeal to moral values.

\subsection{Restrictions}

As noted, the defining feature of many ACs lies in restrictions of the functions that we normally associate with money. For example, LETS and local currencies restrict the exchangeability or purchasing power of money to a given community. Similarly, many green currencies restrict the purchasing power of money to certain goods and services. The restrictions can be more or less stringent, depending on whether, and under what circumstances, users are allowed to convert the ACs into official currencies, and vice versa. In any case, the restrictions are central to the effectiveness of these ACs, because the desired social and environmental effects would disappear without them (Larue 2020a). If local currencies could buy any good produced worldwide, their impact on the local economy would disappear.

In our view, the imposition of these restrictions raises an important ethical issue. This is because they can be understood as a cost that is imposed on the users of the $\mathrm{ACs}$ in question. The cost stems from the reduced freedom that the users enjoy to purchase various goods or services that they desire from the market, which can translate into lower levels of welfare or well-being. In most local communities, for instance, businesses produce far fewer goods that are eligible for the local currency than what consumers can buy with official currencies in a modern supermarket. Therefore, the greater the weight of that local currency in the economy is, the greater are the restrictions imposed on the local citizens' opportunities and freedom to spend their income as they wish.

Of course, proponents of ACs can reply that it is entirely voluntary to adopt ACs. Thus, if that choice involves any costs or restrictions, these are costs that users take on voluntarily. This is a fair counterargument and is especially pertinent in the case of early adopters. However, this reply also points toward a potential problem for ACs. To have a real impact on community integration and environmental sustainability along the lines of our earlier discussion, ACs need to grow and attract a steady stream of new users (Blanc 2018a). Yet growth will likely entail that they would no longer be voluntary, for voluntariness curtails growth. So there is a dilemma here. On one hand, increasing ACs' effectiveness in achieving their objectives requires greater adoption, which comes with the imposition of costs to and restrictions on a larger number of people. On the other hand, leaving people free to decide whether to use these currencies severely curtails the chances of them fulfilling their objectives, for we cannot hope that great numbers of people will spontaneously adopt them. In short, a choice needs to be made between greater effectiveness in achieving their objectives, but at the cost of restrictions on freedom, or free adoption, but at the cost of effectiveness. 


\subsection{Incentives}

As an alternative to restrictions, some ACs seek to influence their users' activities through economic incentives. For example, some proposals of green currencies do not include restrictions but simply give rewards for purchasing products that are more environmentally sustainable (Seyfang 2009). This mechanism is analogous to how commercially designed ACs — such as air miles—work, namely, as a loyalty scheme to incentivize customers to buy more services from a particular company. The use of incentives may be viewed as a way of "nudging" them to do the right thing, which is a milder mechanism than outright restrictions (Thaler and Sunstein 2009). The interesting question is whether we should view such nudges as milder also in an ethical sense or whether they are still ethically problematic.

According to some authors, although incentives may be less coercive than other interventions (such as restrictions), they should still be analyzed as tools for political control, that is, as a way for the state or others to control people's behavior in a certain direction (Grant 2006). An important ethical question is therefore whether, and on what grounds, such control is legitimate. In the literature on nudges, the background justification is often paternalistic, that is, nudges are thought to help us make choices that are better for ourselves or to choose as we would have chosen if we were fully rational and fully informed (Thaler and Sunstein 2009; for an application to investment, see Pilaj 2017). This analysis could be applied to some ACs. As we noted earlier, ACs are often motivated by appeals to social and environmental benefits about which many people care. A case could thus be made for ACs that incentivize people to do the "right" thing.

Another potential justification of incentives, especially when seen as tools for political control, could be that they are the outcomes of a fair collective decisionmaking procedure. When we have differing interests in society, we must often decide on the best course forward through a fair democratic process. Many ACs are motivated precisely by appeals to a more democratic governance of monetary and economic affairs. The incentive structure that they would create may thus be justified for democratic reasons.

To our knowledge, neither the paternalist nor the democratic argument for incentives has ever been used to justify ACs. Although we will come back to the issue of democracy in section 4 , we think more research is needed regarding these questions.

\subsection{Moral Values}

A final mechanism through which some ACs seek to influence their users' activities is an appeal to moral values (Blanc and Fare 2016; Meyer and Hudon 2017, 2019). This mechanism does not make use of hard constraints on people's behavior, nor does it attempt to nudge them through economic rewards. Rather, the purpose is to design ACs to evoke or confirm certain moral attitudes or convictions in their users, such as pro-community or pro-environmental attitudes. As Blanc $(2015,2018 \mathrm{a})$ explains, one can view ACs as having expressive power in the sense that they can communicate users' discontent about the state of contemporary markets. In a similar way, other proponents of ACs conceptualize them as "vectors of contestation," that 
is, as symbolic manifestations of an underlying protest against the market system (Cohen 2017; Guéorguieva-Bringuier and Ottaviani 2018). In short, ACs can promote certain kinds of moral attitudes and thereby foster a desired type of behavior.

We believe that the ethical legitimacy of this mechanism depends on similar questions as in the case of economic incentives. For example, what is the background justification or benefit to users of imposing these moral values? To what extent are these moral values voluntarily accepted versus coercively imposed by the surrounding economic structure? And if they are coercively imposed, can users be said to have a democratic influence on their design? To our knowledge, the literature has not yet discussed any of these questions.

There is also a more basic question with regard to this mechanism, namely, whether it can be expected to work. At least some authors have expressed doubt about whether ACs are likely to be effective as channels of contestation or carriers of moral incentives. An early study of a French LETS found that political contestation constituted at least part of the LETS's appeal among users (Servet et al. 1999). However, a later study on a British LETS found that it had mostly attracted users with low wages or unemployment benefits, who used the AC as a survival strategy (Williams et al. 2001). Similarly, a study on Argentinian Trueques found that many users simply wanted to make some extra money on the side (Gómez 2009). The evidence thus suggests that many users of ACs choose such currencies for economic or nonmoral reasons. However, the literature on the moral values that the currencies evoke or confirm in users is less conclusive.

\section{DEMOCRACY AND DECENTRALIZATION}

In partial contrast with the views discussed previously, it is interesting to note that the AC movement has a different ethical strain, namely, to view ACs as voluntary alternatives in a "monetary plurality" (Lietaer et al. 2012; Larue 2020b). Rather than limiting the freedom of individuals, then, a goal of ACs could be to increase people's freedom to choose whatever currency they like. This idea is expressed in somewhat different terms in different parts of the literature on ACs.

On one hand, proponents of LETS and local currencies typically argue that the power over money creation needs to be reclaimed from private and central banks and put in the hands of users to become more democratic (North 2007). Viewed in this light, local currencies have been interpreted as manifestations of a postcapitalist society based on more democratic ethical values (Cohen 2017). On the other hand, proponents of cryptocurrencies also argue that power over money creation needs to be reclaimed from private banks and central banks, but their arguments here have more to do with a libertarian ideal of freedom from state intervention and/or with economic criticisms of the inflationary tendencies of traditional monetary policies. We discuss these two lines of argument in turn.

\subsection{Democracy}

The first question we may ask in relation to the democratic argument in favor of ACs is what exactly is meant by democracy. A fairly traditional interpretation of 
democracy is that it pertains to the process of electing political representatives to make the official decisions of a state (Przeworski 2019). In that regard, it is debatable whether any currency, whether official or alternative, can be said to be democratic, for elected officials have little, if any, influence on monetary policy (e.g., ContiBrown 2016). What proponents of ACs mean with the term democracy probably has more to do with decentralization and the direct participation of citizens in monetary affairs. In short, what they aim for is perhaps the creation of a "monetary commons" (Meyer and Hudon 2019).

Many ACs have a more decentralized governance system than official currencies, which are governed by central banks. For example, with currencies such as LETS and the Palmas, users are invited to participate in the process of writing the monetary charter and setting the basic rules (Fare, De Freitas, and Meyer 2015). Participation in rule making can take the form of community forums or consultations, often with the objective of engaging all relevant stakeholders, such as local businesses, nonprofits, and citizens/consumers (Siqueira et al. 2020). Local governments can also be active in this process, depending on political willingness and other circumstances (Blanc and Fare 2013). Once implemented, many ACs are also collectively managed on a continual basis. For example, the WIR business-tobusiness currency has a cooperative status that follows the principle of one member/one vote to ensure democratic control, as well as the continuous adaptation to local economic conditions and members' preferences (Kennedy, Lietaer, and Rogers 2012; Vallet 2016). Many other ACs are run in similar ways, allowing members to have a say in the strategic choices of the currency (Kennedy, Lietaer, and Rogers 2012).

Proponents of these practices typically argue that they embody an important aspect of democracy, namely, bottom-up participation and citizen engagement (Blanc 2011; Servet 2013; Seyfang and Longhurst 2013). There is also the background hope that such participation will lead to a more equal distribution of financial resources in society, in comparison with the stark inequalities that characterize the current system of financial capitalism (Barinaga 2020; Ben-Slimane, Justo, and Khelil 2020; Diniz, Siqueira, and van Heck 2019). Perhaps both of these arguments can be summarized by the idea of "the commons."

Despite its appeal, improving the democratic credentials of money may become problematic when the scale of the monetary project increases. A well-known challenge of "direct democracy" in the political realm is that engagement takes both time and energy; therefore people cannot be expected to participate in all decisionmaking but instead have to develop strategies for selecting more specific issues with which to engage. This challenge in turn leads to risks of uneven voter turnout, the influence of special interests, and great inconsistencies in the results of referenda (Fishkin 2011). Such risks seem especially problematic in the monetary realm, because we know that investors prefer an economic environment that is stable and predictable (more on this later). This is one of the central reasons why official currencies nowadays are governed by independent central bankers rather than by elected politicians (Conti-Brown 2016). 


\subsection{Decentralization and Freedom}

The literature on cryptocurrencies can be said to share the concern for decentralization expressed here, although the argumentation is slightly different. First, many proponents of Bitcoin share a libertarian vision of establishing a currency that is beyond the control and oversight of states (Dowd 2014; Golumbia 2016; Kaplanov 2012). Libertarians argue that the state's role should be limited to protecting property rights from theft or fraud and that the state's monopoly over money therefore is illegitimate and wrong (von Hayek 1976). People should be free to choose whatever currency they like, and there should therefore be a plurality of currencies and of monetary institutions.

Second, some also contend that a decentralized monetary system will be more stable and less inflationary than the system we have now, for the latter is plagued by the inflationary tendency of state-run monetary policies (von Hayek 1976; Nakamoto 2008). This argument is similar to the appeal to stability in the literature on "monetary plurality." According to Lietaer et al. (2012), a greater monetary plurality would lead to greater stability, for ACs could replace "failing" currencies in times of crisis and therefore increase the overall resilience of the system. If and when the official currency fails, then, ACs could come in handy.

The literature is certainly correct when it points to flaws and challenges in our current monetary system, which is far from perfect. Over the last twenty years, there have been repeated failures of governance and lack of foresight. However, it is perhaps less clear that a more decentralized system would fare much better. Authors from the more traditional economic camp have warned against the increased economic and financial risks to which decentralization could lead, for instance, because the central bank and/or other authorities would have reduced means of taking emergency action to mitigate potential crises (European Central Bank 2015; Goodhart 2011; Kindleberger and Aliber 2005). Such risks have important repercussions for both the safety and the stability of the monetary system.

Perhaps the clearest evidence for these risks can be found in the recent problems with cryptocurrencies like Bitcoin. Bitcoin uses blockchain technology to remove the need for financial intermediaries like commercial and central banks, and the technology is ultimately administrated by a peer-to-peer network of users (De Filippi and Wright 2018; De Filippi 2015). The short history of Bitcoin has included several security scandals, in which hackers have been able to steal large sums of the currency from online exchanges and deposits (Lambrecht and Larue 2018). The value of Bitcoin relative to official currencies has also varied immensely over the years, which has created uncertainty for users as to the value of their holdings (Brière, Oosterlinck, and Szafarz 2015; De Filippi and Loveluck 2016; Lehdonvirta 2016). Finally, its relative anonymity has made Bitcoin the go-to currency for illegal transactions in drugs and weapons, as well as donations to terrorist organizations (Dierksmeier and Seele 2018).

It is perhaps an exaggeration to suggest that all ACs will suffer from similar problems as Bitcoin, yet we believe that this example gives us reason to rehearse the arguments for why modern societies have opted for more centralized monetary 
governance schemes. First, high degrees of security and reliability are vital for a well-functioning system of payments, in which you can trust that your money will not be lost or suddenly go out of fashion (European Central Bank 2015). Second, as we have learned from historical periods of hyperinflation and other crises, a reasonable level of stability in the value of a currency and other financial assets is vital to the health of an economy. The received way of promoting such stability is through the use of monetary policies, such as countercyclical interventions (Goodhart 2011). Although these arguments can be contested in various ways, they should give us reason to be cautious regarding the merits of decentralization. There is no consensus in the literature regarding the capacity of ACs or a "monetary plurality" to stabilize the economy (Richters and Siemoneit 2017; Larue 2020b). According to Scharding (2019), the overall balance of evidence suggests that traditional national currencies are more likely than decentralized cryptocurrencies to be able to guarantee economic stability and access to basic welfare for all citizens.

To conclude, decentralized monetary arrangements face a number of serious challenges. At the same time, we have seen that there are several values-based arguments for them-including appeals to democracy and the importance of individual freedom. So we are facing a conflict of values here. It is not our role to take a stance in this conflict, and only the future will tell whether the challenges of decentralization can be overcome in some way.

\section{CONCLUSION AND FURTHER RESEARCH}

With a growing number of AC initiatives worldwide, we believe that it is important and timely to analyze the ethical implications of these currencies from a broader social, political, and economic perspective. The overarching aim of this article has been to stimulate further and more ambitious philosophical debate about ACs in the future. We close by developing some of the research questions our review has highlighted.

First, we connected debates on the classification of ACs with a philosophical discussion about the nature of money. Our discussion suggested that both the functionalist account of money, which is popular in economics, and the collective acceptance view of money, which is promoted by Searle, can be used to theorize about the money-like features of ACs. We said that it is likely that different ACs fare differently well in terms of both functionality and collective acceptance. Therefore a potentially fruitful avenue for further research could be to consider the connections between different ontological views and particular ACs in greater detail.

A second area of research relates to the ethical issues of markets and money. We highlighted how ACs could contribute to improving social cohesion and mitigating environmental harm, yet we also showed that ACs face two challenges. First, more effort needs to be put into increasing the effectiveness of ACs' impact on the environment. Second, impact should not come at the expense of people in the Global South who are already worse off than others. Addressing these challenges and tensions is likely to require input from both normative and empirical researchers. 
A third interesting area of research concerns the mechanisms that ACs employ to address these issues, which include restrictions, incentives, and appeals to moral values. We have argued that the effectiveness of these mechanisms is inherently connected to the fairness of their consequences. Further philosophical analysis is needed of the ethical justifications for restricting the purchasing power of money to local circumstances and for nudging people's behavior through monetary schemes.

Finally, a fourth area relates to debates about democracy and decentralization. According to our analysis, there is indeed potential in the idea of increasing citizens' participation in monetary affairs. However, we have also noted several challenges of decentralization related to the efficiency of monetary governance and policy. We hope that future research can contribute to mitigating these challenges and to addressing the apparent conflict of values that is inherent in society's choice of a monetary system.

\section{Acknowledgments}

The authors thank Jasmine C. Elliott, Richard Endörfer, Nina van Heeswijk, Georg Schmerzeck, and Adrian Walsh, as well as three anonymous reviewers and the editor of this journal, for their insightful comments and suggestions on the article.

\section{REFERENCES}

Barinaga, Ester. 2020. "A Route to Commons-Based Democratic Monies? Embedding the Governance of Money in Traditional Communal Institutions." Frontiers in Blockchain. DOI: 10.3389/fbloc.2020.575851.

Barnett, Michael L., Irene Henriques, and Bryan W. Husted. 2020 "Beyond Good Intentions: Designing CSR Initiatives for Greater Social Impact.” Journal of Management 46 (6): 937-64.

Barontini, Christian, and Henry Holden. 2019. "Proceeding with Caution-a Survey on Central Bank Digital Currency." Paper 101, Bank for International Settlements, Basel, Switzerland. https://www.bis.org/publ/bppdf/bispap101.htm.

Bech, Morten, and Rodney Garratt. 2017. "Central Bank Cryptocurrencies.” BIS Quarterly Review, September, 55-70. https://www.bis.org/publ/qtrpdf/r_qt1709f.htm.

Ben-Slimane, Karim, Rachida Justo, and Nabil Khelil. 2020. "Institutional Entrepreneurship in a Contested Commons: Insights from Struggles Over the Oasis of Jemna in Tunisia." Journal of Business Ethics 166 (4): 673-90.

Blanc, Jérôme. 2011. "Classifying 'CCs': Community, Complementary and Local Currencies.” International Journal of Community Currency Research 15 (D): 4-10.

Blanc, Jérôme. 2013. "Penser la pluralité des monnaies à partir de Polanyi: un essai de typologie." In Socioéconomie et démocratie: l'actualité de Karl Polanyi, edited by Isabelle Hillenkamp and Jean-Louis Laville, 241-70. Toulouse, France: Erès.

Blanc, Jérôme. 2015. "Contester par projets: le cas des monnaies locales associatives." Revue de la régulation 18 (Autumn).

Blanc, Jérôme. 2017. "Unpacking Monetary Complementarity and Competition: A Conceptual Framework." Cambridge Journal of Economics 41 (1): 239-57.

Blanc, Jérôme. 2018a. Les monnaies alternatives. Paris: La Découverte. 
Blanc, Jérôme. 2018b. "Making Sense of the Plurality of Money: A Polanyian Attempt." In Monetary Plurality in Local, Regional and Global Economies, edited by Georgina M. Gómez, 48-66. Abingdon, UK: Routledge.

Blanc, Jérôme, and Marie Fare. 2013. "Understanding the Role of Governments and Administrations in the Implementation of Community and Complementary Currencies." Annals of Public and Cooperative Economics 84 (1): 63-81.

Blanc, Jérôme, and Marie Fare. 2016. "Turning Values Concrete: The Role and Ways of Business Selection in Local Currency Schemes." Review of Social Economy 74 (3): 298-319.

Bowles, Samuel. 1998. "Endogenous Preferences: The Cultural Consequences of Markets and Other Economic Institutions." Journal of Economic Literature 36 (1): 75-111.

Bowring, Finn. 1998. "LETS: An Eco-Socialist Initiative?" New Left Review 232 (December): 91-111.

Boyce, James K. 2018. “Carbon Pricing: Effectiveness and Equity.” Ecological Economics 150 (August): 52-61.

Brière, Marie, Kim Oosterlinck, and Ariane Szafarz. 2015. "Virtual Currency, Tangible Return: Portfolio Diversification with Bitcoin.” Journal of Asset Management 16 (6): 365-73.

Brooks, Skylar. 2015. "How Green Is Our Money? Mapping the Relationship between Monetary Systems and the Environment." International Journal of Community Currency Research 19 (D): 12-18.

Cleveland, David A., Allison Carruth, and Daniella Niki Mazaroli. 2015. "Operationalizing Local Food: Goals, Actions, and Indicators for Alternative Food Systems.” Agriculture and Human Values 32 (2): 281-97.

Cohen, Boyd. 2017. "The Rise of Alternative Currencies in Post-capitalism." Journal of Management Studies 54 (5): 739-46.

Collins, Josh Ryan, Ludwig Schuster, and Tony Greenham. 2013. Energizing Money: An Introduction to Energy Currencies and Accounting. London: New Economics Foundation.

Conti-Brown, Peter. 2016. The Power and Independence of the Federal Reserve. Princeton, NJ: Princeton University Press.

de Bruin, Boudewijn, Lisa Herzog, Martin O’Neill, and Joakim Sandberg. 2018. "Philosophy of Money and Finance." In The Stanford Encyclopedia of Philosophy, edited by Edward N. Zalta. https://plato.stanford.edu/archives/win2018/entries/ money-finance/.

De Filippi, Primavera. 2014. "Bitcoin: A Regulatory Nightmare to a Libertarian Dream." Internet Policy Review 3 (2).

De Filippi, Primavera. 2015. "Translating Commons-Based Peer Production Values into Metrics: Toward Commons-Based Cryptocurrencies." In Handbook of Digital Currency, edited by David Lee Kuo Chuen, 463-83. San Diego, CA: Academic Press.

De Filippi, Primavera, and Benjamin Loveluck. 2016. "The Invisible Politics of Bitcoin: Governance Crisis of a Decentralized Infrastructure." Internet Policy Review 5 (4).

De Filippi, Primavera, and Aaron Wright. 2018. Blockchain and the Law: The Rule of Code. Cambridge, MA: Harvard University Press.

Degens, Philipp. 2016. "Between 'Market' and 'Reciprocity': How Businesses Use Local Currencies." Behemoth 9 (2): 22-36.

Delmas, Magali A., and Vanessa Cuerel Burbano. 2011. "The Drivers of Greenwashing." California Management Review 54 (1): 64-87. 
Dierksmeier, Claus, and Peter Seele. 2018. "Cryptocurrencies and Business Ethics.” Journal of Business Ethics 152 (1): 1-14.

Dietsch, Peter, François Claveau, and Clément Fontan. 2018. Do Central Banks Serve the People? Cambridge: Polity Press.

Diniz, Eduardo H., Erica S. Siqueira, and Eric van Heck. 2019. "Taxonomy of Digital Community Currency Platforms." Information Technology for Development 25 (1): 69-91.

Dittmer, Kristofer. 2013. "Local Currencies for Purposive Degrowth? A Quality Check of Some Proposals for Changing Money-as-Usual.” Journal of Cleaner Production 54: $3-13$.

Dowd, Kevin. 2014. New Private Monies: A Bit-Part Player? London: Institute of Economic Affairs.

Etzioni, Amitai. 1988. The Moral Dimension: Toward a New Economics. New York: Free Press.

European Central Bank. 2015. Virtual Currency Schemes: A Further Analysis. Frankfurt am Main, Germany: European Central Bank. https://www.ecb.europa.eu/pub/pdf/other/ virtualcurrencyschemesen.pdf.

European Council. 1989. Report on Economic and Monetary Union in the European Community. Luxembourg: Office for Official Publications of the European Communities.

Fantacci, Luca. 2005. "Complementary Currencies: A Prospect on Money from a Retrospect on Premodern Practices." Financial History Review 12 (1): 43-61.

Fantacci, Luca. 2008. "The Dual Currency System of Renaissance Europe." Financial History Review 15 (1): 55-72.

Fare, Marie, Carlos De Freitas, and Camille Meyer. 2015. "Territorial Development and Community Currencies: Symbolic Meanings in Brazilian Community Development Banks." International Journal of Community Currency Research 19 (D): 6-17.

Fare, Marie, and Pepita Ould Ahmed. 2017. "Complementary Currency Systems and Their Ability to Support Economic and Social Changes." Development and Change 48 (5): 847-72.

Ferguson, Benjamin, and Christopher Thompson. 2021. "Why Buy Local?" Journal of Applied Philosophy 38 (1): 104-20.

Fishkin, James S. 2011. When the People Speak: Deliberative Democracy and Public Consultation. Oxford: Oxford University Press.

Giovannoni, Elena, and Giacamo Fabietti. 2013. "What Is Sustainability? A Review of the Concept and Its Applications." In Integrated Reporting, edited by Cristiano Busco, Mark Frigo, Angelo Riccaboni, and Paolo Quattrone, 21-40. Cham, Switzerland: Springer.

Golumbia, David. 2016. The Politics of Bitcoin. Minneapolis: University of Minnesota Press.

Gómez, Georgina M. 2009. Argentina's Parallel Currency: The Economy of the Poor. London: Pickering and Chatto.

Gómez, Georgina M. 2018. Monetary Plurality in Local, Regional and Global Economies. New York: Routledge.

Goodhart, Charles A. E. 2011. "The Changing Role of Central Banks." Financial History Review 18 (2): 135-54.

Grant, Ruth W. 2006. "Ethics and Incentives: A Political Approach.” American Political Science Review 100 (1): 29-39.

Gregory, Lee. 2009. "Spending Time Locally: The Benefit of Time Banks for Local Economies." Local Economy 24 (4): 323-33. 
Guéorguieva-Bringuier, Laura, and Fiona Ottaviani. 2018. "Opposition and Isomorphism with the Neoliberal Logic in Community Exchange Systems.” Ecological Economics 149 (July): 88-97.

Hacking, Ian. 1999. The Social Construction of What? Cambridge, MA: Harvard University Press.

Hindriks, Frank, and Francesco Guala. 2015. "Institutions, Rules, and Equilibria: A Unified Theory." Journal of Institutional Economics 11 (3): 459-80.

Hindriks, Frank, and Francesco Guala. 2021. "The Functions of Institutions: Etiology and Teleology." Synthese 198: 2027-43.

Hodgson, Geoffrey M. 2019. "Taxonomic Definitions in Social Science, with Firms, Markets and Institutions as Case Studies." Journal of Institutional Economics 15 (2): 207-33.

Huber, Joseph, and James Robertson. 2000. Creating New Money: A Monetary Reform for the Information Age. London: New Economics Foundation.

Joachain, Hélène, and Fédéric Klopfert. 2012. "Emerging Trend of Complementary Currencies Systems as Policy Instruments for Environmental Purposes: Changes Ahead?" International Journal of Community Currency Research 16 (D): 156-68.

Joachain, Hélène, and Frédéric Klopfert. 2014. "Smarter than Metering? Coupling Smart Meters and Complementary Currencies to Reinforce the Motivation of Households for Energy Savings." Ecological Economics 105 (September): 89-96.

Kaplanov, Nikolei M. 2012. "Nerdy Money: Bitcoin, the Private Digital Currency, and the Case against Its Regulation." Loyola Consumer Law Review 25 (1): 111-74.

Kennedy, Margrit I., Bernard A. Lietaer, and John Rogers. 2012. People Money: The Promise of Regional Currencies. Axminster, UK: Triarchy Press.

Kindleberger, Charles P., and Robert Z. Aliber. 2005. Manias, Panics and Crashes. London: Palgrave Macmillan.

Kumhof, Michael, and Clare Noone. 2018. “Central Bank Digital Currencies-Design Principles and Balance Sheet Implications.” Working Paper 725, Bank of England, London. https://papers.ssrn.com/abstract=3180713.

Kuroda, Akinobu. 2008. "Concurrent but Non-integrable Currency Circuits: Complementary Relationships among Monies in Modern China and Other Regions." Financial History Review 15 (1): 17-36.

Lambrecht, Maxime, and Louis Larue. 2018. “After the (Virtual) Gold Rush: Is Bitcoin More than a Speculative Bubble?" Internet Policy Review 7 (4).

Larue, Louis. 2020a. "A Conceptual Framework for Classifying Currencies.” International Journal of Community Currency Research 24 (1): 45-60.

Larue, Louis. 2020b. "The Ecology of Money: A Critical Assessment." Ecological Economics 178 (December): Article 106823.

Lehdonvirta, Vili. 2016. The Blockchain Paradox: Why Distributed Ledger Technologies May Do Little to Transform the Economy. Oxford: Oxford Internet Institute.

Lepofsky, Jonathan D. 2009. "Strange Exchange: Using a Complementary Currency to Rearticulate Ethics, Place and Community." Ethics, Place, and Environment 12 (1): 131-42.

Lietaer, Bernard A., Christian Arnsperger, Sally Goerner, and Stefan Brunnhuber. 2012. Money and Sustainability: The Missing Link. Axminster, UK: Triarchy Press.

Lietaer, Bernard A., and Margrit Kennedy. 2008. Monnaies régionales de nouvelles voies vers une prospérité durable. Translated by Vincent Guimard. Paris: Editions Charles Léopold Mayer. 
Liket, Kellie. 2014. "Why 'Doing Good' Is Not Good Enough: Essays on Social Impact Measurement." PhD diss., Erasmus University Rotterdam.

Marshall, Adam P., and Daniel W. O’Neill. 2018. "The Bristol Pound: A Tool for Localisation?" Ecological Economics 146 (April): 273-81.

Martignoni, Jens. 2012. "A New Approach to a Typology of Complementary Currencies." International Journal of Community Currency Research 16 (A): 1-17.

Meyer, Camille, and Marek Hudon. 2017. "Alternative Organizations in Finance: Commoning in Complementary Currencies." Organization 24 (5): 629-47.

Meyer, Camille, and Marek Hudon. 2019. "Money and the Commons: An Investigation of Complementary Currencies and Their Ethical Implications." Journal of Business Ethics 160 (1): 277-92.

Michel, Arnaud, and Marek Hudon. 2015. "Community Currencies and Sustainable Development: A Systematic Review." Ecological Economics 116 (August): 160-71.

Mill, John Stuart. (1859) 1974. On Liberty. Harmondsworth, UK: Penguin.

Mora, Camilo, Randi L. Rollins, Katie Taladay, Michael B. Kantar, Mason K. Chock, Mio Shimada, and Erik C. Franklin. 2018. "Bitcoin Emissions Alone Could Push Global Warming above $2^{\circ} \mathrm{C}$." Nature Climate Change 8 (11): 931-33.

Nakamoto, Satoshi. 2008. "Bitcoin: A Peer-to-Peer Electronic Cash System.” http://www. bitcoin.org/bitcoin.pdf.

Niepelt, Dirk. 2020. "Reserves for All? Central Bank Digital Currency, Deposits, and Their (Non)-Equivalence." International Journal of Central Banking 16 (3): 211-38.

North, Peter. 2007. Money and Liberation: The Micropolitics of Alternative Currency Movements. Minneapolis: University of Minnesota Press.

Oliver Sanz, Esther. 2016. "Community Currency (CCs) in Spain: An Empirical Study of Their Social Effects.” Ecological Economics 121 (January): 20-27.

Peacock, Mark S. 2000. "Local Exchange Trading Systems: A Solution to the Employment Dilemma?" Annals of Public and Cooperative Economics 71 (1): 55-78.

Pilaj, Herwig. 2017. "The Choice Architecture of Sustainable and Responsible Investment: Nudging Investors toward Ethical Decision-Making." Journal of Business Ethics 140 (4): 743-53.

Place, Christophe, and Leander Bindewald. 2015. "Validating and Improving the Impact of Complementary Currency Systems through Impact Assessment Frameworks." International Journal of Community Currency Research 19: 152-64.

Polanyi, Karl. (1944) 2001. The Great Transformation: The Political and Economic Origins of Our Time. 2nd ed. Princeton, NJ: Beacon Press.

Przeworski, Adam. 2019. Crises of Democracy. Cambridge: Cambridge University Press.

Richters, Oliver, and Andreas Siemoneit. 2017. "Consistency and Stability Analysis of Models of a Monetary Growth Imperative." Ecological Economics 136 (June): 114-25.

Rousseaux, Sandrine. 2010. État des lieux international des programmes de carte carbone individuelle. Report 09 10 C 0110. Vanves, France: Agence de l'Environnement et de la Maîtrise de l'Énergie.

Sandel, Michael J. 1984. "The Procedural Republic and the Unencumbered Self." Political Theory 12 (1): 81-96.

Sandel, Michael J. 2012. What Money Can't Buy: The Moral Limits of Markets. New York: Farrar, Straus, and Giroux.

Scharding, Tobey. 2019. "National Currency, World Currency, Cryptocurrency: A Fichtean Approach to the Ethics of Bitcoin." Business and Society Review 124 (2): 219-38. 
Schnell, Steven M. 2013. "Food Miles, Local Eating, and Community Supported Agriculture: Putting Local Food in Its Place." Agriculture and Human Values 30 (4): 615-28.

Seabright, Paul. 2004. The Company of Strangers: A Natural History of Economic Life. Princeton, NJ: Princeton University Press.

Searle, John R. 1995. The Construction of Social Reality. New York: Simon and Schuster.

Searle, John R. 2010. Making the Social World: The Structure of Human Civilization. Oxford: Oxford University Press.

Searle, John R. 2015. "Status Functions and Institutional Facts: Reply to Hindriks and Guala." Journal of Institutional Economics 11 (3): 507-14.

Servet, Jean-Michel. 2013. "Monnaie: quand la dette occulte le partage." Revue Française de Socio-Économie 12 (2): 125-47.

Servet, Jean-Michel, Denis Bayon, Jérôme Blanc, Isabelle Guérin, Gilles Malandrin, and David Vallat. 1999. Une économie sans argent: les systèmes d'echange local. Paris: Éditions du Seuil.

Seyfang, Gill. 2002. "Tackling Social Exclusion with Community Currencies: Learning from LETS to Time Banks." International Journal of Community Currency Research 6.

Seyfang, Gill. 2009. "Carbon Currencies: A New Gold Standard for Sustainable Consumption?" CSERGE Working Paper EDM 09-07, University of East Anglia, Norwich, UK.

Seyfang, Gill, and Noel Longhurst. 2013. "Growing Green Money? Mapping Community Currencies for Sustainable Development." Ecological Economics 86 (February): $65-77$.

Simmel, Georg. 2004. The Philosophy of Money. London: Routledge.

Siqueira, Ana Cristina O., Benson Honig, Sandra Mariano, and Joysi Moraes. 2020. “A Commons Strategy for Promoting Entrepreneurship and Social Capital: Implications for Community Currencies, Cryptocurrencies, and Value Exchange." Journal of Business Ethics 166 (4): 711-26.

Smit, J. P., Filip Buekens, and Stan du Plessis. 2016. "Cigarettes, Dollars and Bitcoins—an Essay on the Ontology of Money." Journal of Institutional Economics 12 (2): 327-47.

Taylor, Charles. 1991. The Malaise of Modernity. Concord, ON: Anansi.

Thaler, Richard H., and Cass R. Sunstein. 2009. Nudge: Improving Decisions about Health, Wealth, and Happiness. New York: Penguin Books.

Tichit, Ariane, Clément Mathonnat, and Diego Landivar. 2016. "Classifying Non-bank Currency Systems Using Web Data." International Journal of Community Currency Research 20: 24-40.

Titmuss, Richard Morris. 1970. The Gift Relationship: From Human Blood to Social Policy. London: Allen and Unwin.

Tobin, James. 2008. "Money." In New Palgrave Dictionary of Economics, edited by Steven F. Durlauf and Lawrence E. Blume, 2nd ed., 1-15. Basingstoke, UK: Palgrave Macmillan.

Tuomela, Raimo. 2002. The Philosophy of Social Practices: A Collective Acceptance View. Cambridge: Cambridge University Press.

United Nations. 2015. "Transforming Our World: The 2030 Agenda for Sustainable Development." https://sdgs.un.org/2030agenda.

Vallet, Guillaume. 2016. “A Local Money to Stabilize Capitalism: The Underestimated Case of the WIR.” Economy and Society 45 (3-4): 479-504. 
von Hayek, Friedrich A. 1976. Denationalisation of Money. London: Institute of Economic Affairs.

Walzer, Michael. 1983. Spheres of Justice: A Defense of Pluralism and Equality. New York: Basic Books.

Williams, Colin C. 1996. "Local Exchange and Trading Systems: A New Source of Work and Credit for the Poor and Unemployed?" Environment and Planning 28 (8): 1395-415.

Williams, Colin C., Theresa J. Aldridge, Roger Lee, Andrew Leyshon, Nigel Thrift, and Jane Tooke. 2001. "Bridges into Work? An Evaluation of Local Exchange and Trading Schemes (LETS).” Policy Studies 22 (2): 119-32.

Yermack, David. 2015. "Is Bitcoin a Real Currency? An Economic Appraisal." In Handbook of Digital Currency, edited by David Lee Kuo Chuen, 31-43. San Diego, CA: Academic Press.

LOUIS LARUE (louis.larue.2@gu.se, corresponding author) is a researcher in practical philosophy at the University of Gothenburg, Sweden. His research focuses on issues of justice in finance and money and on several topics in the philosophy of economics. He also has an interest in social ontology.

Camille Meyer is senior lecturer in social innovation and entrepreneurship at the University of Cape Town Graduate School of Business, South Africa. His research focuses on community and cross-sector collaborations in social entrepreneurship and the governance of commons. He received his PhD from the SBS-EM at Université Libre de Bruxelles.

MAREK HUdON is professor at the Solvay Brussels School of Economics and Management, Université Libre de Bruxelles, Belgium. He is also codirector of the Centre for European Research in Microfinance (CERMi) and director of the Centre d'Etudes Economiques et Sociales de l'Environnement (CEESE). His research mainly focuses on social and nonprofit enterprises, sustainable development, and business ethics.

JOAKIM SANDBERG is professor of practical philosophy at University of Gothenburg, Sweden, as well as professor of economics and finance from a humanist perspective at University of Groningen, the Netherlands. He is director of the Financial Ethics Research Group in Gothenburg. He does research in the intersections between moral and political philosophy and studies in business and economics.

This is an Open Access article, distributed under the terms of the Creative Commons Attribution licence (https://creativecommons.org/licenses/by/4.0/), which permits unrestricted re-use, distribution, and reproduction in any medium, provided the original work is properly cited. 